\title{
Indirect Cytotoxicity of a 35\% Hydrogen Peroxide Bleaching Gel on Cultured Odontoblast-Like Cells
}

\author{
Cármen Regina COLDEBELLA ${ }^{1}$ \\ Ana Paula Dias RIBEIRO ${ }^{2}$ \\ Nancy Tomoko SACONO ${ }^{1}$ \\ Flávia Zardo TRINDADE² \\ Josimeri HEBLING ${ }^{1}$ \\ Carlos Alberto de Souza COSTA ${ }^{3}$
}

\author{
${ }^{1}$ Department of Orthodontics and Pediatric Dentistry, Araraquara Dental School, \\ São Paulo State University, Araraquara, SP, Brazil \\ ${ }^{2}$ Department of Dental Materials and Prosthodontics, Araraquara Dental School, \\ São Paulo State University, Araraquara, SP, Brazil \\ ${ }^{3}$ Department of Physiology and Pathology, Araraquara Dental School, São Paulo State University, Araraquara, SP, Brazil
}

\begin{abstract}
The aim of this study was to evaluate the trans-enamel and trans-dentinal effects of a $35 \%$ hydrogen peroxide $\left(\mathrm{H}_{2} \mathrm{O}_{2}\right)$ bleaching gel on odontoblast-like cells. Enamel/dentin discs obtained from bovine incisors were mounted in artificial pulp chambers (APCs). Three groups were formed: $\mathrm{G} 1-35 \% \mathrm{H}_{2} \mathrm{O}_{2} ; \mathrm{G} 2-35 \% \mathrm{H}_{2} \mathrm{O}_{2}+$ halogen light application; G3- control. The treatments were repeated 5 times and the APCs were incubated for $12 \mathrm{~h}$. Then, the extract was collected and applied for $24 \mathrm{~h}$ on the cells. Cell metabolism, total protein dosage and cell morphology were evaluated. Cell metabolism decreased by $62.09 \%$ and $61.83 \%$ in G1 and G2, respectively. The depression of cell metabolism was statistically significant when G1 and G2 were compared to G3. Total protein dosage decreased by $93.13 \%$ and $91.80 \%$ in G1 and G2, respectively. The cells in G1 and G2 exhibited significant morphological alterations after contact with the extracts. Regardless of halogen light application, the extracts caused significantly more intense cytopathic effects compared to the control group. After 5 consecutive applications of a $35 \% \mathrm{H}_{2} \mathrm{O}_{2}$ bleaching agent, either catalyzed or not by halogen light, products of gel degradation were capable to diffuse through enamel and dentin causing toxic effects to the cells.
\end{abstract}

Key Words: tooth bleaching, hydrogen peroxide, odontoblasts, cytotoxicity.

\section{INTRODUCTION}

Pulp necrosis and deposition of secondary dentin as a result of pulp aging are usually associated with alterations on tooth color. Other events such as dental developmental disorders (e.g.: amelogenesis imperfeita), exposure to high doses of fluorides or tetracycline and trauma, may also cause darkening of teeth (1).

Due to its reactive properties, hydrogen peroxide $\left(\mathrm{H}_{2} \mathrm{O}_{2}\right)$ is the main active chemical component of most agents used in tooth bleaching therapies. $\mathrm{H}_{2} \mathrm{O}_{2}$ can be used in its pure form or as the final product of the degradation of other bleaching substances, such as carbamide peroxide or sodium perborate (2). The dissociation of
$\mathrm{H}_{2} \mathrm{O}_{2}$ into water, reactive oxygen and some free radical species promotes a whitening effect on the dental hard tissues because these reactive molecules attack the long-chained, dark-colored chromophore molecules and split them into smaller, less colored and more diffusible molecules $(2,3)$.

In order to bleach the teeth, $\mathrm{H}_{2} \mathrm{O}_{2}$ must penetrate through the enamel to reach the underlying dentin (4), which is mostly responsible for tooth color. However, in vitro studies have demonstrated that due to its low molecular weight, $\mathrm{H}_{2} \mathrm{O}_{2}$ even at low concentrations can diffuse through the dentinal tubules and reach the pulp chamber (5). This intrapulpal penetration of $\mathrm{H}_{2} \mathrm{O}_{2}$ is influenced by a number of factors including the bleach- 
ing time and osmotic pressure of the bleaching gel (6), gel concentration (7) and number of bleaching sessions needed to obtain the desired tooth color (8).

$\mathrm{H}_{2} \mathrm{O}_{2}$ may act as an oxidant agent by the formation of free radical species, such as hydroxyl radicals $\left(\mathrm{OH}^{-}\right)$, which are either generated by the organism during cell metabolic activity in the mitochondria or acquired via exogenous sources (9). In contact with the pulp tissue, these free radicals may cause oxidative stress to the pulp cells due to the unbalance between the production of reactive oxygen species (ROS) and the presence of endogenous and exogenous antioxidants. The increase of ROS levels causes deleterious effects to several cell components, including damage to cellular DNA (genotoxicity and carcinogenesis), protein oxidation and fragmentation, lipid peroxidation and even induction of cell apoptosis and necrosis (9). According to Seale et al. (10), $\mathrm{H}_{2} \mathrm{O}_{2}$ alone or catalyzed by heat induces dentin deposition and causes alterations in the odontoblasts, which are typical cells of the pulp tissue and are organized in a monolayer that underlies the coronal and root dentin (11).

Cell damages caused by peroxides have been extensively investigated (6) because vital tooth bleaching therapies using gels with high concentrations of these chemical agents is one of the most common clinical procedures in contemporary esthetic dentistry. However, little is known about the cytotoxic effects of bleaching gel components that are capable to diffuse through enamel and dentin and reach the pulp cells. Therefore, the aim of this study was to evaluate the trans-enamel and transdentinal cytotoxicity of a bleaching gel containing 35\% $\mathrm{H}_{2} \mathrm{O}_{2}$ on cultures of odontoblast-like cells (MDPC-23).

\section{MATERIAL AND METHODS}

\section{Preparation of Discs}

Fifteen sound bovine incisors were collected and scaled for removal of periodontal tissue remnants and other debris. The teeth were mounted in a precision cutting machine (Isomet 1000; Buehler Ltda., Lake Bluff, IL, USA) and a rectangular slab involving enamel and dentin was cut transversally from the middle third of the buccal surface of each tooth. The slabs were rounded and refined with a water-cooled high-speed cylindrical diamond bur (\#1095; KG Sorensen, Barueri, SP, Brazil) until obtaining 5.2-mm-diameter discs. The discs were examined with a stereomicroscope (SZ2-ILST; Olym- pus Corporation, Tokyo, Japan) and only those with no enamel defects were selected. Dentin surface was polished with wet 400- and 600-grit silicon carbide paper (T469SF; Saint-Gobain Abrasivos Ltda., Jundiaí, SP, Brazil) reaching a standardized enamel and dentin thicknesses of 1.3 and $2.2 \mathrm{~mm}$, respectively. The final thickness of the enamel/dentin discs was $3.5 \mathrm{~mm}$, as measured with a digital caliper (Model 500-144B, Mitutoyo Sul América Ltda., São Paulo, SP, Brazil). A 0.5 M ethylenediaminetetraacetic acid (EDTA) solution, $\mathrm{pH}$ 7.2, was applied on dentin surface during $30 \mathrm{~s}$ for smear layer removal and the discs were thoroughly rinsed with sterile deionized water.

\section{Artificial Pulp Chambers (APCs)}

Each enamel/dentin disc was adapted individually to an APC, a device presenting an upper and a lower compartment in which circular perforations permitted free diffusion of the culture medium between the outer and inner portions of the APC (12). The discs were positioned in the APCs between 2 silicon rings $(4.47 \mathrm{~mm}$ inner diameter; $1.78 \mathrm{~mm}$ thick; Rodimar Rolamentos Ltda, Araraquara, SP, Brazil), which promoted a lateral seal between the upper and lower compartments of the device. The APCs with the discs in position were autoclaved at $120^{\circ} \mathrm{C}$ for $20 \mathrm{~min}$.

\section{Culture of MDPC-23 Cells}

Immortalized cells of the odontoblast-like cell line (MDPC-23) were cultured in Dulbecco's Modified Eagle's Medium (DMEM; Sigma Chemical Co., St. Louis, MO, USA) supplemented with $10 \%$ fetal bovine serum (Gibco, Grand Island, NY, USA), with 100 IU/ $\mathrm{mL}$ penicillin, $100 \mu \mathrm{g} / \mathrm{mL}$ streptomycin and $2 \mathrm{mmol} / \mathrm{L}$ glutamine (Gibco) in an humidified incubator with 5\% $\mathrm{CO}_{2}$ and $95 \%$ air at $37^{\circ} \mathrm{C}$ (Isotemp; Fisher Scientific, Pittsburgh, PA, USA). The MDPC-23 cells were subcultured every 3 days until an adequate number of cells were obtained for the study. The cells were then seeded $\left(50,000\right.$ cells $\left./ \mathrm{cm}^{2}\right)$ in 30 wells of sterile 24 -well plates (Costar Corp., Cambridge, MA, USA), which were maintained in the humidified incubator with $5 \% \mathrm{CO}_{2}$ and $95 \%$ air at $37^{\circ} \mathrm{C}$ for $48 \mathrm{~h}$.

\section{Bleaching Procedure}

A bleaching gel containing $35 \%$ of $\mathrm{H}_{2} \mathrm{O}_{2}$ in its 
formulation (Whiteness HP; FGM Produtos Odontológicos Ltda, Joinville, SC, Brazil) was used in the present study. For the bleaching procedure, the 15 APCs with the dentin/enamel discs in position were placed individually in the wells of sterile 24-well plates, containing 1 $\mathrm{mL}$ of culture medium (DMEM) per well. The enamel surface of the discs was faced upwards in order to be completely exposed to receive the bleaching treatments (12). The APCs with the dentin/enamel discs were randomly assigned to 3 groups $(n=5)$, according to the treatment performed on the enamel surface of the discs: G1: $35 \% \mathrm{H}_{2} \mathrm{O}_{2}$ bleaching gel application for $15 \mathrm{~min}$; G2: $35 \% \mathrm{H}_{2} \mathrm{O}_{2}$ bleaching gel application for $15 \mathrm{~min}$ plus halogen light activation for $20 \mathrm{~s}$; G3: control (no treatment). Ten milligrams of the bleaching gel were used in the bleached groups.

The halogen light source (Curing Light XL 3000; 3M ESPE, St Paul, MN, USA) used in G2 following gel application had an output power of $430 \mathrm{~mW} / \mathrm{cm}^{2}$, as measured with a curing radiometer (Demetron; Kerr Corp., Danbury, CT, USA). During light exposure, the light guide tip of the curing unit was held at $10 \mathrm{~mm}$ from enamel surface. In G1 and G2, the bleaching gel was left in contact with the enamel surface for $15 \mathrm{~min}$ and was then aspirated carefully with sterile Pasteur pipettes (Corning Inc., Corning, NY, USA). The bleaching procedure was repeated 5 consecutive times, totalizing $75 \mathrm{~min}$ of contact the bleaching agent with the enamel surface (G1 and G2), and $100 \mathrm{~s}$ of light activation (G2).

\section{Bleaching Gel Extracts}

After the fifth and last application, the bleaching gel was aspirated and the enamel surface was thoroughly rinsed with $1 \mathrm{~mL}$ of sterile deionized water with concomitant aspiration. The APCs with the discs in position were then incubated for $12 \mathrm{~h}$ in $5 \% \mathrm{CO}_{2}$ and $95 \%$ air atmosphere at $37^{\circ} \mathrm{C}$. After this period, $1 \mathrm{~mL}$ of extract, which is the culture medium containing the products of bleaching gel degradation that diffused through enamel and dentin, was collected from each well and divided in aliquots of $500 \mu \mathrm{L}$. The extracts were applied in 30 wells of 24-well plates ( 10 wells per group; $500 \mu \mathrm{L}$ of extract per well) containing previously cultured MDPC23 cells. The extracts were left in contact with cells for $24 \mathrm{~h}$ in the humidified incubator with $5 \% \mathrm{CO}_{2}$ and $95 \%$ air at $37^{\circ} \mathrm{C}$ (Isotemp; Fisher Scientific, Pittsburgh, PA, USA). In the non-bleached control group, the extracts were represented by culture medium (DMEM).

\section{Analysis of Cell Metabolism (MTT Assay)}

In each group, 6 out of 10 wells were used for analysis of cell metabolism by the cytochemical demonstration of succinic dehydrogenase (SDH) activity, which is a measure of the mitochondrial respiration of the cells, ${ }^{22}$ employing the methyl tetrazolium (MTT) assay.

For the MTT assay, the extracts were aspirated and replaced by $900 \mu \mathrm{L}$ of DMEM plus $100 \mu \mathrm{L}$ of MTT solution $(5 \mathrm{mg} / \mathrm{mL}$ sterile PBS; Sigma Chemical Co., St. Louis, MO, USA). Thereafter, the culture medium with the MTT solution were aspirated and replaced by $600 \mu \mathrm{L}$ of acidified isopropanol solution $(0.04 \mathrm{~N} \mathrm{HCl})$ in each well to dissolve the formazan crystals resulting from the cleavage of the MTT salt ring by the SDH enzyme present in the mitochondria of viable cells. Three $100 \mu \mathrm{L}$ aliquots of each well were transferred to 96-well plates (Costar Corp., Cambridge, MA, USA). Cell viability was evaluated by spectrophotometry as being proportional to the absorbance measured at 570 $\mathrm{nm}$ wavelength with an ELISA microplate reader (model 3550-UV, Bio-Rad Laboratories, Hercules, CA, USA).

The values obtained from the 3 aliquots were averaged to provide a single value for each well. The means were calculated for the groups and transformed into percentages, which represented the inhibitory effect of the mitochondrial activity of the cells by the extracts. The negative control (DMEM) was defined as having $100 \%$ of cell metabolism. The data obtained from the MTT assay were analyzed statistically by Mann-Whitney's test at 5\% significance level.

\section{Analysis of Cell Morphology}

Cell morphology was examined by scanning electron microscopy (SEM) using one representative wells of each group. For such purpose, sterile 12-mm-diameter cover glasses (Fisher Scientific) were placed on the bottom of the wells of sterile 24-well plates immediately before seeding of the MDPC-23 cells. Then, the extracts were applied on the cells and the plates were incubated for $24 \mathrm{~h}$, in the same way as described before. Following this period, the extracts were aspirated and the viable cells that remained adhered to the glass substrate were fixed in $1 \mathrm{~mL}$ of buffered $2.5 \%$ glutaraldehyde for 60 $\min$. The cells were the subjected to three 5-min rinses 
with $1 \mathrm{~mL}$ PBS, post-fixed in $1 \%$ osmium tetroxide for $60 \mathrm{~min}$ and processed for examination with a scanning electron microscope (JEOL-JMS-T33A; JEOL, Tokyo, Japan).

\section{Total Protein Dosage}

The remaining 3 wells in each group were used for total protein dosage. The culture medium was aspirated and the cells were washed three times with $2 \mathrm{~mL}$ PBS heated at $37^{\circ} \mathrm{C}$. Two milliliters of $0.1 \%$ sodium lauryl sulfate (Sigma Chemical Co., St. Louis, MO, USA) were added to each well and maintained for 40 min at room temperature to produce cell lysis. The samples were homogenized and $1 \mathrm{~mL}$ from each well was transferred to properly labeled Falcon tubes (Corning Incorporated). One milliliter of distilled water was added to the blank tube. Next, $1 \mathrm{~mL}$ of Lowry reagent solution (Sigma Chemical Co.) was added to all tubes, which were agitated for $10 \mathrm{~s}$ in a tube agitator (Phoenix AP 56, Araraquara, SP, Brazil). After $20 \mathrm{~min}$ at room temperature, $500 \mu \mathrm{L}$ of Folin-Ciocalteau's phenol reagent solution (Sigma Chemical Co.) were added to each tube followed by 10 -s agitation. Thirty min later, three $100 \mu \mathrm{L}$ aliquots of each tube were transferred to a 96-well plate and the absorbance of the test and blank tubes was measured at $655 \mathrm{~nm}$ wavelength with an ELISA microplate reader (model 3550-UV, Bio-Rad Laboratories, Hercules, CA, USA). Total protein dosage was calculated by multiplying the absorbance obtained in the test by the calibration factor.

\section{RESULTS}

SDH activity data, detected by the MTT assay, are described in Figure 1. The highest activity of SDH was observed for the control group (DMEM) which was statistically different from the other 2 groups $(\mathrm{p}<0.05)$.

Considering the control group (G3) as having $100 \%$ of cell metabolism, the metabolic activity of the viable MDPC-23 cells that remained attached to glass substrate in $\mathrm{G} 1$ and G2 decreased by $62.09 \%$ and $61.83 \%$, respectively. Statistical analysis of the data from the MTT assay showed that the $35 \% \mathrm{H}_{2} \mathrm{O}_{2}$ bleaching gel caused severe toxic effects to the odontoblastlike cell (MDPC-23) cultures, but the gel catalyzed by halogen light (G2) did not have its cytotoxicity significantly increased compared to the application of bleaching gel alone (G1) ( $p>0.05)$. Regardless of halogen light association, the extracts obtained after repeated applications of the bleaching gel on enamel surface caused significantly more intense cytopathic effects compared to the non-bleached control group $(\mathrm{p}<0.05)$.

Total protein dosage decreased by $93.13 \%$ and $91.80 \%$ in G1 and G2, respectively.

The cells in G1 and G2 presented significant morphological alterations, exhibiting a rounded shape and few thin and short cytoplasmic processes originating from their membrane. Fragments of the cytoplasmic membrane of lethality damaged cells that detached from the cover glasses were observed on different areas of the substrate (Figs. 2 and 3). The experimental groups G1 and G2 presented a significiantly smaller number of odontoblast-like cells (MDPC-23) adhered to the glass substrate. In G3, however, numerous MDPC-23 cells near confluence remained adhered to the cover glasses. The glass substrate was almost completely covered by MDPC-23 cells with a large cytoplasm. Morphologically, the MDPC-23 cells were spindle-shaped and exhibited numerous thin and long cytoplasmatic processes originating from the cell membrane, which seemed to be keeping the cells attached to the glass substrate (Fig. 4).

\section{DISCUSSION}

It has been demonstrated that the application de $\mathrm{H}_{2} \mathrm{O}_{2}$ on enamel produces porosities due to the protein

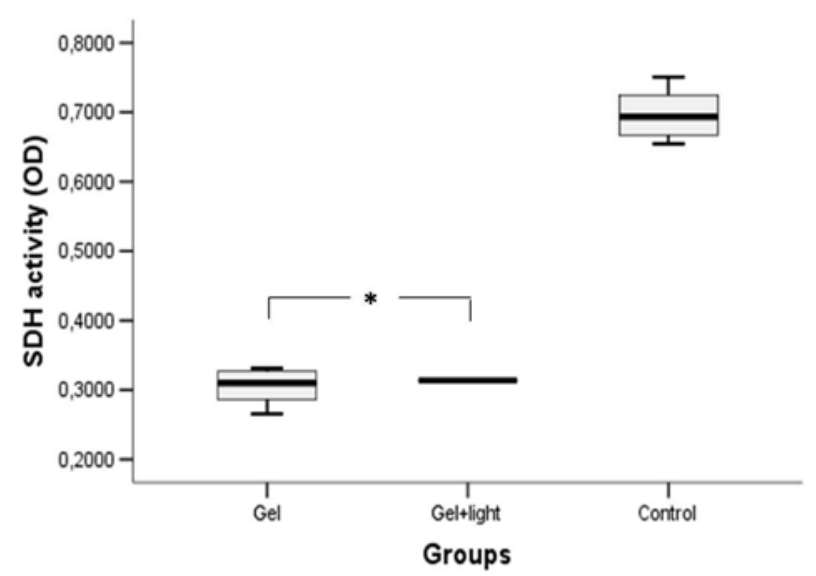

Figure 1. Box-whisker plot (minimum [lower quartile-medianupper quartile] maximum) of the SDH activity (MTT assay) for each group $(\mathrm{n}=6)$. * Groups (columns) connected by the horizontal line do no differ statistically (Mann-Whitney, $\mathrm{p}>0.05$ ). 
matrix dissolution caused by the intense oxidative effect of the free radicals resulting from bleaching gel degradation (13). Studies have reported that due to its low molecular weight, the $\mathrm{H}_{2} \mathrm{O}_{2}$ present in the bleaching gels can diffuse easily through dentin to reach the pulp chamber (4-6). A previous investigation evaluating the in vitro penetration of bleaching agents into the pulp chamber (14) demonstrated the occurrence of diffusion of a large amount of $\mathrm{H}_{2} \mathrm{O}_{2}$ through the enamel and dentin of bovine teeth. However, it was not determined whether the amount of products leached from the bleaching gel that reached the pulp space would be sufficient to cause damage to the pulp cells.

In view of these results in the literature, the
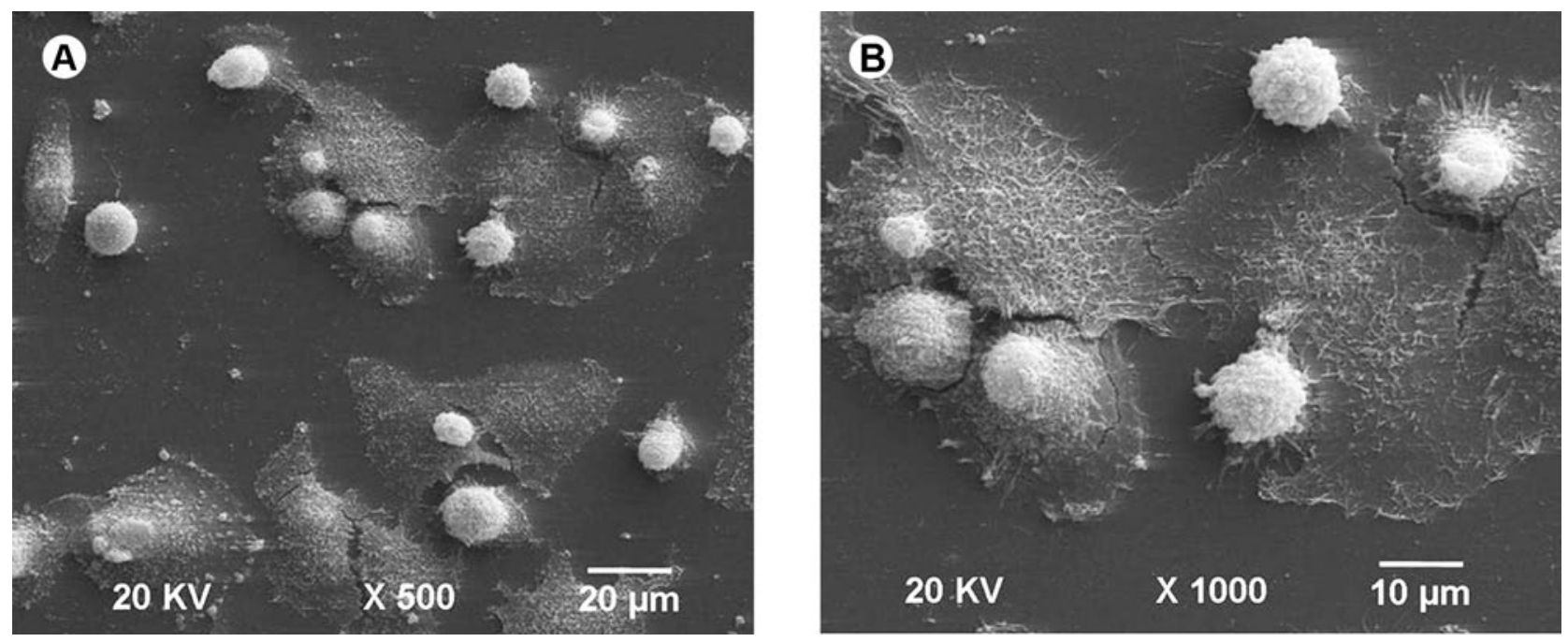

Figure 2. SEM micrographs of G1 (bleaching gel): A = Few MDPC-23 cells remained adhered to the glass substrate $(\times 500$ original magnification); $\mathrm{B}=$ Greater magnification of " $\mathrm{A}$ " showing that cytoskeletal shrinkage reduced significantly the cell size, leaving large cell-free areas on the cover glass surface $(\times 1000$ original magnification $)$.
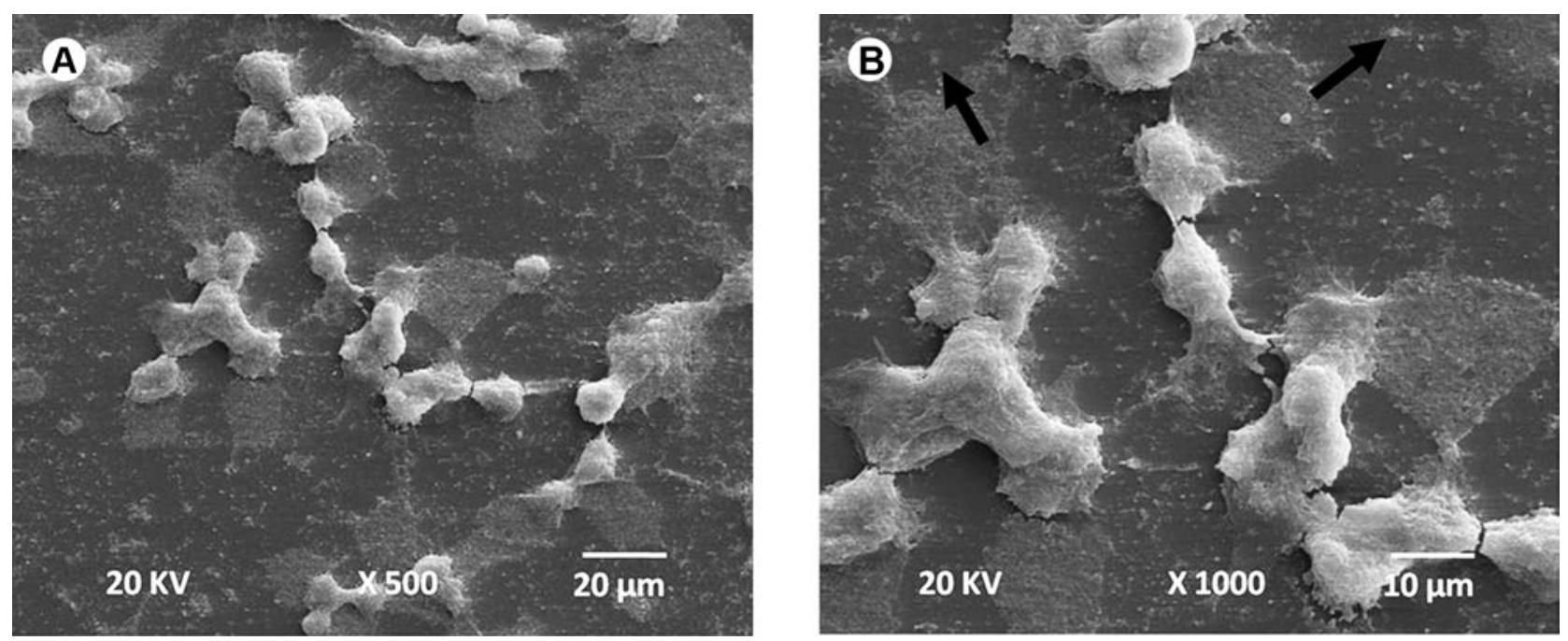

Figure 3. SEM micrographs of G2 (bleaching gel + halogen light): A = Few MDPC-23 cells remained adhered to the glass substrate ( $\times 500$ original magnification); $\mathrm{B}=$ Greater magnification of "A" showing small-sized cells, leaving large cell-free areas on the cover glass surface to which rests of the cytoplasmic membrane of lethally damaged cells are adhered (arrows) $(\times 1000$ original magnification). 
present study evaluated the possible cytotoxic effects of products released from a $35 \% \mathrm{H}_{2} \mathrm{O}_{2}$ bleaching gel on cultured pulp cells. Although there is no consensus in the literature regarding the most indicated cell type to evaluate the in vitro cytotoxicity of dental products, mouse dental papillae cells (MDPC-23 cells) have been widely used, especially for being cells with odontoblast phenotype (15). In mammalian teeth, the odontoblasts are organized in a monolayer that underlies the coronal and root dentin (11). Therefore, any chemical agent that is capable to diffuse through the enamel and dentinal tubules will interact first with these peripheral pulp cells, which play an important role in pulp healing. Some in vitro studies have employed dentin barriers to evaluate the possible toxic effects of some dental materials (16). As bleaching agents are applied to enamel surface, biological barriers (enamel/dentin discs) were used in the present study in order to simulate in vitro a situation as close as possible to the clinical condition. The goal was to investigate whether the trans-enamel and transdentinal diffusion of a bleaching gel with high $\mathrm{H}_{2} \mathrm{O}_{2}$ concentration widely used in in-office vital bleaching therapies, either catalyzed or not by halogen light, and the products of its degradation would cause potential toxic effects to pulp cell culture.

Bovine teeth were used because their structural characteristics, such as number and diameter of dentinal tubules, are similar to those of human teeth (17). The thickness of the bovine enamel/dentin discs used in the present study $(3.5 \mathrm{~mm} ; 1.3 \mathrm{~mm}$ enamel and $2.2 \mathrm{~mm}$ dentin) was comparable to that described by Suleiman et al. (4) for human teeth (0.9 to $1.05 \mathrm{~mm}$ enamel and $2.33 \mathrm{~mm}$ dentin).

In some cases, several bleaching sessions are needed to reach the desired esthetic outcome (8). However, it is known that the aggressiveness of a bleaching gel depends not only on its application time on enamel (10), but also on the $\mathrm{H}_{2} \mathrm{O}_{2}$ concentration in the product. The increase of the bleaching time may result in a deeper penetration of the components released from the bleaching gel, which may cause severe damage to the pulp tissue $(10,18)$. The penetration of $\mathrm{H}_{2} \mathrm{O}_{2}$-based bleaching agents into the dental structure causes different alterations in vital teeth (3) and some products resulting from $\mathrm{H}_{2} \mathrm{O}_{2}$ degradation, such as $\mathrm{OH}^{-}$and other $\mathrm{ROS}$, may cause lipid peroxidation and protein fragmentation with consequent cell membrane damage (9). Thus, the oxidative effects of the free radicals resulting from the bleaching process may cause cell apoptosis and necrosis (18).

A previous study showed that the application of a $33 \% \mathrm{H}_{2} \mathrm{O}_{2}$ bleaching gel for $30 \mathrm{~min}$ on the enamel of canine teeth was capable to produce damage to odontoblast-like cells and internal inflammatory root resorption (10). In the present study, in addition to us-
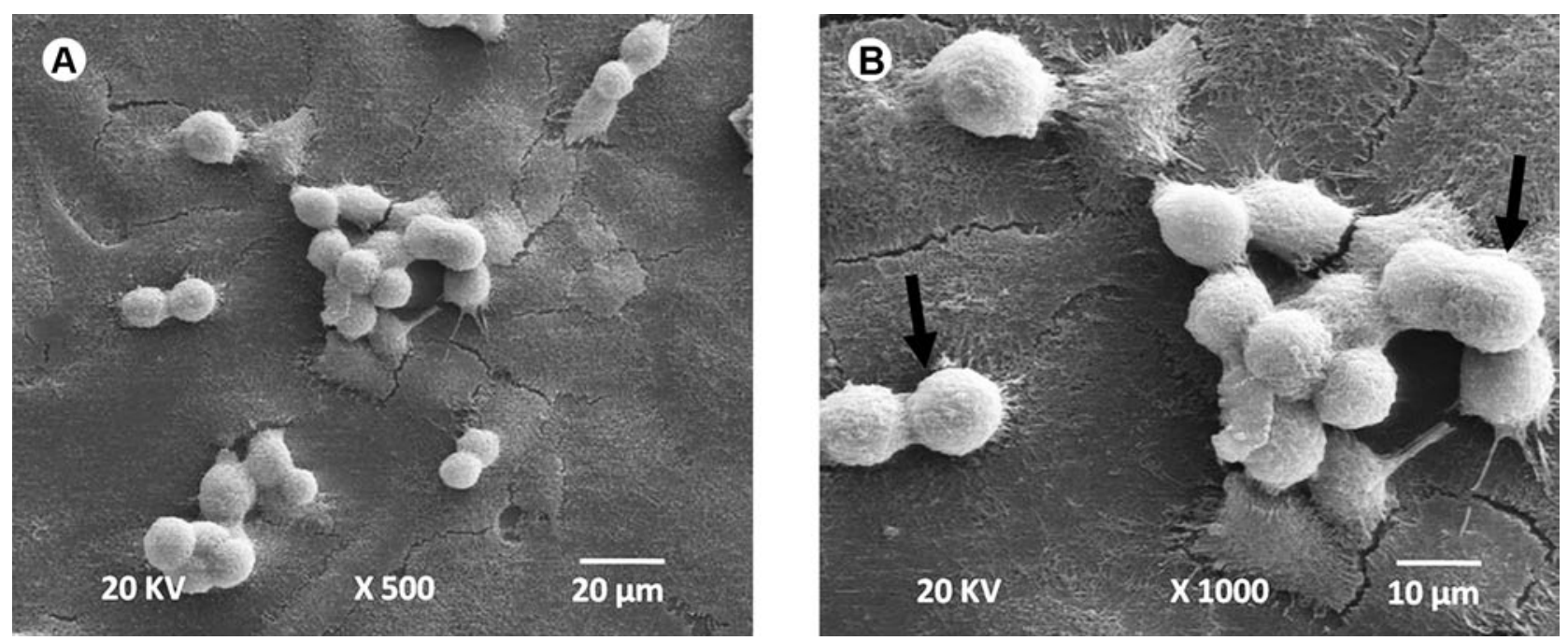

Figure 4. SEM micrographs of G3 (control group): A = Numerous MDPC-23 cells, near confluence, remained adhered to the glass substrate $(\times 500$ original magnification $)$; $\mathrm{B}=$ Greater magnification of " $\mathrm{A}$ " showing that the glass substrate is almost completely covered by MDPC-23 cells with a large cytoplasm. Numerous thin cytoplasmic processes originating from the cell membrane and mitotic cells (arrows) can also be observed $(\times 1000$ original magnification). 
ing teeth with structural characteristics and hard tissue thickness similar to those of human teeth, a long total bleaching time was established (75 min, distributed in five 15-min consecutive applications) in order to simulate a frequent clinical situation in vital tooth bleaching therapies to whiten severely darkened teeth. Although the concentration of the gel components in the culture medium was not determined in the different groups, it was possible to demonstrate that the chemicals that diffused through enamel and dentin caused severe toxic effects to the MDPC-23 cells. Therefore, although agents with high $\mathrm{H}_{2} \mathrm{O}_{2}$ concentrations (30-35\%) are considered as the most effective for in-office bleaching therapies (3), in the present study this product caused severe cytopathic effects, which were characterized by the SEM analysis as direct cell death or significant morphological alterations in the odontoblast-like cells cultures.

In addition to the bleaching time and $\mathrm{H}_{2} \mathrm{O}_{2}$ concentration in the gel, the catalytic effect of heat on the bleaching gel should also be considered. It has been reported that the heating produced by the application of a light source (e.g.: halogen lamp), accelerates the reaction of $\mathrm{H}_{2} \mathrm{O}_{2}$ decomposition, accelerating the bleaching process (8). In the present study, halogen light associated with the $35 \% \mathrm{H}_{2} \mathrm{O}_{2}$ bleaching gel (G2) did not promote a statistically significant greater decrease in cell metabolism compared to gel application alone (G1) (Fig. 1). In both groups, there was a decrease in total protein dosage and cell number. The cells that remained adhered to the glass substrate were round shaped and presented few cytoplasmic processes originating from the cell membrane. The remarkable decrease of total protein dosage and the decrease by approximately $60 \%$ of cell metabolism observed in G1 and G2 occurred not only due to the inhibition of cell activity, but also because a large number of cells were lethality damaged and detached from the glass substrate after death (Figs. 2 and 3 ). It may be speculated that the similar cytotoxic effects observed in $\mathrm{G} 1$ and $\mathrm{G} 2$ are due to the fact that the 5 consecutive applications of the bleaching gel promoted deep structural alterations in the dental hard tissues (13), permitting an intense diffusion of the products of gel degradation through enamel and dentin.

In this sense, when the bleaching gel is repeatedly applied, halogen light application seems not to increase the cytotoxicity of the product. The findings of a recent study (19) showed that extracts collected after three consecutive applications of a $35 \% \mathrm{H}_{2} \mathrm{O}_{2}$ bleaching gel caused severe toxic effects on cultured odontoblast-like cells MDPC-23, and these cytopathic effects were not increased significantly when the bleaching gel was activated with a halogen light source. Again, these results suggest that several applications of bleaching gels with high $\mathrm{H}_{2} \mathrm{O}_{2}$ concentrations may cause intense alterations to the hard dental tissues, which, regardless of light application, would permit the diffusion of bleaching gel components across enamel and dentin to reach the pulp cells. However, further studies should be performed to evaluate the damages to the hard tissues of teeth subjected to multiple bleaching sessions as well as the diffusion rate of products of bleaching gel degradation and their toxic effects to pulp cells.

It is evident that the results of in vitro studies cannot be directly extrapolated to clinical situations (20). Vital teeth present a dentinal fluid flow produced by intrapulpal pressure, cytoplasmic processes of odontoblasts and other intratubular components, which may aid reducing bleaching gel diffusion through the dentinal tubules (6). In addition, the dental pulp presents a lymphatic vessel system that participates in the elimination of external products that reach this tissue by trans-dentinal diffusion. Furthermore, due to the oxidative stress generated by the presence of free radicals, the defense system of the pulp cells is activated, releasing several endogenous antioxidant agents, such as peroxidases and catalases, which promotes an enzymatic degradation of hydrogen peroxide to avoid excessive tissue damage (20).

In spite of the excellent esthetic outcomes obtained with bleaching gels with high $\mathrm{H}_{2} \mathrm{O}_{2}$ concentration, previous studies have shown that these agents may cause cell damage both in vitro and in vivo (18). It has been demonstrated that the cell damages occur mainly due to the diffusion of products of bleaching gel degradation $(4,14)$. Future research should be performed to develop tooth bleaching techniques that offer good clinical results without promoting an intense diffusion of toxic products at sufficiently high concentrations to cause irreversible damage to the pulp cells.

Under the tested experimental conditions, it may be concluded that the extracts obtained through the transenamel and trans-dentinal diffusion of products of a $35 \%$ $\mathrm{H}_{2} \mathrm{O}_{2}$ bleaching gel degradation caused toxic effects to the odontoblast-like cell line (MDPC-23) cultures. The irradiation of the bleaching gel with halogen light did not influence the cytopathic effects of this dental product. 


\section{RESUMO}

O objetivo deste estudo foi avaliar os efeitos citotóxicos de um agente clareador com $35 \%$ de peróxido de hidrogênio $\left(\mathrm{H}_{2} \mathrm{O}_{2}\right)$ sobre células da linhagem odontoblástica. Foram confeccionados discos de esmalte/dentina obtidos de incisivos bovinos, os quais foram posicionados em câmaras pulpares artificiais (CPAs). Três grupos foram formados: G1: gel clareador; G2: gel clareador + luz halógena e G3: controle. Após 5 aplicações consecutivas do gel clareador sobre o esmalte, os extratos foram obtidos e aplicados por $24 \mathrm{~h}$ sobre as células. Foram realizadas avaliações do metabolismo celular, morfologia das células e expressão total de proteína. O metabolismo celular para G1 e G2 reduziu em 62,09\% e $61,83 \%$, respectivamente. A redução do metabolismo celular foi estatisticamente significante quando se comparou G1 e G2 com G3. A expressão de proteína total reduziu em 93,13\% e 91,80\% para G1 e G2, respectivamente. As células em G1 e G2 apresentaram importantes alterações morfológicas após contato com os extratos. Foi possível concluir que independente da catalização ou não do gel clareador por luz halógena, os componentes que se difundiram através dos tecidos duros do dente após sua quinta aplicação sobre o esmalte, causaram intensos efeitos citotóxicos para as células.

\section{REFERENCES}

1. Watts A, Addy M. Tooth disclouration and staining: a review of the literature. Br Dent J 2001;190:309-316.

2. Dahl JE, Pallesen U. Tooth bleaching. A critical review of the biological aspects. Crit Rev Oral Biol Med 2003;14:292-304.

3. Auschill TM, Hellwig E, Schmidale S, Sculean A, Arweiler NB. Efficacy, side-effects and patient's acceptance of different bleaching techniques (OTC, in-office, at-home). Oper Dent 2005;30:156163.

4. Sulieman M, Addy M, Rees JS. Surface and intra-pulpal temperature rises during tooth bleaching: an in vitro study. Br Dent $\mathrm{J}$ 2005;199:37-40.

5. Gökay O, Müjdeci A, Algn E. Peroxide penetration into the pulp from whitening strips. J Endod 2004;30:887-889.

6. Hanks CT, Fat JC, Wataha JC, Corcoran JF. Cytotoxicity and dentin permeability of carbamide peroxide and hydrogen-peroxide vital bleaching materials, in vitro. J Dent Res 1993;72:931-938.

7. Gökay O, Yilmaz F, Akin S, Tunçbìlek M, Ertan R. Penetration of the pulp chamber by bleaching agents in teeth restored with various restorative materials. J Endod 2000;26:92-94.
8. Buchalla W, Attin T. External bleaching therapy with activation by heat, light or laser - a systematic review. Dent Mater 2007;23:586596.

9. Martindale JL, Holbrook NJ. Cellular response to oxidative stress: signaling for suicide and survival. J Cell Physiol 2002;192:1-15.

10. Seale NS, McIntosh JE, Taylor AN. Pulpal reaction to bleaching of teeth in dogs. J Dent Res 1981;60:948-953.

11. Goldberg M, Smith AJ. Cells and extracellular matrices of dentin and pulp: a biological basis for repair and tissue engineering. Crit Rev Oral Biol Med 2004;15:13-27.

12. Trindade FZ, Ribeiro APD, Sacono NT, Oliveira CF, Lessa FCR, Hebling J, et al.. Trans-enamel and trans-dentinal cytotoxic effects of a $35 \% \mathrm{H} 2 \mathrm{O} 2$ bleaching agent on an odontoblast cell line after consecutive applications. Int Endod J 2009;42:516-524.

13. Kwon YH, Huo MS, Kim KH, Kim SK, Kim YJ. Effects of hydrogen peroxide on the light reflectance and morphology of bovine enamel. J Oral Rehabil 2002;29:473-477.

14. Benetti AR, Valera MC, Mancini MNG, Miranda CB, Baldicci I. In vitro penetration of bleaching agents into the pulp chamber. Int Endod J 2004;37:120-124.

15. Costa CAS, Duarte PCT, Souza PPC, Giro EMA, Hebling J. Cytotoxic effects and pulpal response caused by a mineral trioxide aggregate formulation and calcium hydroxide. Am J Dent 2007:21:255-261.

16. Lanza CR, de Souza Costa CA, Furlan M, Alécio A, Hebling J. Transdentinal diffusion and cytotoxicity of self-etching adhesive systems. Cell Biol Toxicol 2009;25:533-543.

17. Camargo SEA, Valera MC, Camargo CHR, Mancini MNG, Menezes MM. Penetration of $38 \%$ hydrogen peroxide into the pulp chamber in bovine and human teeth submitted to office bleach technique. J Endod 2007;33:1074-1077.

18. Fukuyama Y, Ohta K, Okoshi R, Kizaki H, Nakagawa K. Hydrogen peroxide induces expression and activation of AMP-actived protein kinase in a dental pulp cell line. Int End J 2008;41:197-203.

19. Ribeiro APD, Sacono NT, Lessa FCR, Nogueira I, Coldebella CR; Hebling J, et al.. Cytotoxic effect of a $35 \%$ hydrogen peroxide bleaching gel on odontoblast-like MDPC-23 cells. Oral Surg Oral Med Oral Pathol Oral Radiol Endod 2009;108:458-464.

20. Esposito P, Varvara G, Murmura G, Terlizzi A, Caputi S. Ability of healthy and inflamed human dental pulp to reduce hydrogen peroxide. Eur J Oral Sci 2003;111:454-456.

Accepted October 16, 2009 